\title{
FOREIGN TRADE POLICY FOR INTEGRATION INTO GLOBAL VALUE CHAINS
}

\author{
Igor Guzhva', Petro Nebotov², Yevhen Ivanov ${ }^{3}$
}

\begin{abstract}
The purpose of the article is to define and argue the key criteria and directions of foreign trade policy, which become crucial in conditions of country's integration into global value chains, as well as to reveal the impact of major regulatory barriers to trade that prevent Ukraine's integration into global value chains. The subject-matter of the study is the peculiarities of foreign trade regulation under global value chains expansion. Methodology. The methodological principles of research involve the joint application of a set of well-known common scientific methods, as well as special research methods in economics, such as the method of system and structural analysis to generalize spheres, directions, and tools of GVC-friendly trade regulation. Results. The essence of global value chains as a modern concept for international trade analysis is revealed. New approaches to trade and economic policy aimed at improving the country's participation in global value chains are analysed. Key spheres, in which bottlenecks for global value chains usually occur, are investigated. The growing importance of liberalization of trade in services in order to integrate into GVC successfully is stressed. Main barriers that prevent the Ukrainian economy from effective integration into GVC are outlined. Basic shortcomings in Ukraine's export control system that constrain the expansion of the country's exports of dual-use goods and technologies are outlined. Practical implications. The article contains a comprehensive set of tools and regulations to revise approaches, directions, and efficiency criteria of governmental foreign trade policy according to global value chains concept. Value/originality. Identified requirements for foreign trade policy allowed investigating the effectiveness and perspectives of Ukraine's trade and investment regime from a GVC point of view.
\end{abstract}

Key words: government regulation, global value chains, market access, trade facilitation, trade infrastructure, barriers to trade, export control.

JEL Classification: F13, F15, F68

\section{Introduction}

The modern territorial organization of transnational corporations was formed under the influence of irreversible processes of deepening the international division of labour, the main role in which played componential specialization. This contributed to the development of a qualitatively new form of international cooperation - the global value chains (GVCs). The diversification of production processes across different regions and countries contributes to a steep reduction in trade costs through the development of information and communication technologies. This factor has a tremendous impact on the acceleration of globalization, as it leads to inclusion of new markets and entire countries in the world reproduction process, stimulates the diffusion of innovations, scientific and technological advance, creation of new jobs.
GVCsemergedasstrategiesfororganizinggeographically dispersed industries into a single, effective complex based on their specialization and complementarity for the production of a particular end product or service. In GVCs, each country generates not the full value of the goods but takes part in the generation of value added at some stage of goods' development, production, and marketing. This reduces costs and improves the competitiveness of products by placing individual stages of production where it is the most beneficial. Consequently, radical transformations take place, which determines the participation of countries in the international division of labour at different stages of production, taking into account the technological level, features of competition, access to resources and international markets. This necessitates a revision of the principles of industrial and foreign trade policy of the government.

\footnotetext{
Corresponding author:

${ }^{1}$ State Research Institute for Informatization and Modeling of Economy, Ukraine.

E-mail:mfertua@gmail.com

${ }^{2}$ State Research Institute for Informatization and Modeling of Economy, Ukraine.

E-mail: petr_nebotov@ukr.net

${ }^{3}$ State Research Institute for Informatization and Modeling of Economy, Ukraine.

E-mail: eivanov.dndiime@gmail.com
} 
The study of foreign trade policy effectiveness in the context of integration into GVCs is a relatively new approach in present economic thought. However, due to a number of methodological advantages, the global scientific and business community became increasingly interested in trade-related issues associated with GVCs. The economists such as Cattaneo (2010), Nicita (2013), Gereffi (2010), Frederick (2010), Barrientos (2010), dedicated their investigation to the GVCs issues. On the other hand, existing studies analyse the criteria for integration into the GVC primarily in the context of developing a favourable investment climate, while the trade aspects of government regulation in this area are covered in a fragmented and non-systematic way.

The purpose of the article is to define and argue the key criteria and directions of foreign trade policy, which become crucial in conditions of country's integration into GVCs, as well as to reveal the impact of major regulatory barriers to trade that prevent Ukraine's integration into the GVCs.

\section{Adaptation of foreign trade policy to global value chains expansion}

Undoubtedly, the development of GVC is a positive result of globalization, as it allows the inclusion of nearly all countries in the global economy. This contributes to their economic and social development. Moreover, for the struggling countries and those without significant internal growth drivers, the integration into GVC is perhaps the only possibility of qualitative inclusion in the system of global capital flows and the international flows of goods and services. But the benefits and opportunities of participating in GVCs require enterprises to be able to deliver the products in the right amount, at the right quality and price, and at the right time. The benefit of GVCs participation may be high, but the same applies to entry requirements. And these requirements are put forward not only to business but also to the authorities.

Formation and support of GVCs is a complex process that requires their organizers (mostly TNCs) to systematically study the conditions of economic activity and the efficiency of engaging in a global supply chains when choosing foreign suppliers or opening subsidiaries. Under these conditions, the main objective of the foreign trade policy is the ability of the national economy to meet the criteria for effective involvement and participation in GVCs, which is a determining factor of countries' integration into the world economy.

This factor is vital for developing countries and transitional economies because participation in GVCs forms their main and often the only possibility to intensify trade relations, attract foreign investments and high technologies, which, in turn, will contribute to qualitative restructuring and diversification of their exports, increasing the possibility of using positive trends of world economy development and leading to international competitiveness growth (UNCTAD, 2014).

In general, the use of GVC for economic development requires revision of established approaches to the trade and economic policy on a number of issues, both nationally and internationally. First, as import components become an important source of increasing competitiveness for exports, approaches and criteria of customs and tariff policy are necessary to revise. The calculation of protection degree should take into account not only the duties on finished products but also duties on imported components to exclude situations when components are protected at a higher rate than finished products. In order to develop exports, it is necessary also to reduce anti-export offsets of promising producers of high value-added products that arise in the case of longterm high tariff protection.

Secondly, as modern international production is characterized by uneven participation of companies in GVCs, the revision of general protectionism model is also required. About $80 \%$ of world trade takes place within or with the participation of transnational corporations. Protection of their interests in such conditions drives government away from protectionism at national borders to the protectionism of existing chains by means of: cost reduction, simplification of trade procedures for multiple unimpeded border crossings, promotion of unified regulatory systems and protection of intellectual property rights across the world. This leads to a correction of the protectionist model: stimulation of materials and components import is desirable when connected with the perspective of increase of finished products exports (Park, 2013).

Thirdly, the modification of the protectionist model changes the agenda for bilateral and multilateral trade negotiations and the content of the agreements concluded on their basis. To defend and promote interests of the GVCs participants, the following agreements are elaborated: WTO Trade Facilitation Agreement (TFA) signed in 2013 to reduce transaction costs in international trade; Trade in Services Liberalization Agreement launched in 2012 outside the WTO system in order to reduce barriers to services markets access; Anti-Counterfeiting Trade Agreement signed by $22 \mathrm{EU}$ members or the protection of intellectual property rights, etc.

Fourthly, the integration agenda of key countries and blocs of the world also undergo a radical transformation. Granting preferences for existing GVCs becomes the main objective of international economic integration. For this purpose, free trade agreements, in addition to tariff issues, increasingly include issues aimed at reducing other trade costs for GVCs (liberalization of trade in services, trade facilitation, restrictions on the use of local components, etc.), as well as measures aimed at protecting the established GVC (rules of origin, protection of intellectual property rights, 
competition rules, etc.). Thus, the formation of deep and comprehensive free trade zones becomes a distinctive feature of up-to-dateness.

At the level of an individual country, the effectiveness of foreign trade policy in this context is achieved by elimination of a variety of obstacles (both at the border of the customs territory and for economic activity within the country) to guarantee predictable and uninterrupted movement of goods and services (Figure 1), since engagement in global GVCs is mediated by international trade and investment flows (Koval et. al., 2018).

According to Figure 1, internationally-accepted methodology distinguishes nine main areas of government competence related to the international movement of goods and services that may raise barriers to foreign trade activities:

a) market access includes a variety of tariff and nontariff measures that discriminate foreign competitors in favour of domestic producers;

b) customs effectiveness reflects the speed and ease of customs clearing, the quality and range of services provided by the customs authorities. The poor work of the customs authorities reflects in ineffective resources allocation and in rejection of the best world practices, resulting in unnecessary inspections and additional time spent during customs procedures;

c) burden of customs procedures goes beyond the customs administration and reflects the effectiveness of coordinating its activities with other agencies for trade regulation and control, as well as with customs authorities of neighbouring countries; d) transparency of customs authorities reflects the barriers associated with corruption in relevant services that may be embodied in "simplification payments" to reduce procedures duration or in additional delays in the case of a refusal to give a bribe;

e) availability and quality of transport infrastructure reflect the access to airports, the quality of automobile roads and railway, traffic congestion in ports and various characteristics of other vehicles. Unsatisfactory road, rail, sea or air transport networks can be a major burden, especially when moving goods over long distances;

f) availability and quality of transport services reflect the effectiveness of government regulation of the market of transport and logistics services, which is aimed at eliminating the monopolization of these markets and providing favourable conditions for the development of all possible types of relevant services in the domestic market;

g) availability and application of information and communication technologies reflect the scope of paper documentary elimination in favour of electronic record-keeping by state bodies, transport and logistics companies in the field of tracking and controlling the movement of goods and services;

h) regulatory environment reflects the quality of the country's legislative environment related to potential costs and risks of foreign trade operations as a part of the investment process. First of all, it concerns the regime of foreign labour hiring, peculiarities of foreign exchange regulation in foreign trade, the level of liberalization of international capital flows, etc.

\begin{tabular}{|c|c|c|c|}
\hline \multicolumn{4}{|c|}{ Key barriers to GVCs } \\
\hline Market access & $\begin{array}{c}\text { Customs } \\
\text { administration }\end{array}$ & Infrastructure & $\begin{array}{l}\text { Investment } \\
\text { regime }\end{array}$ \\
\hline $\begin{array}{l}\text { 1. Barriers to } \\
\text { exports and } \\
\text { imports: } \\
\text { - tariffs; } \\
\text { - quantitative } \\
\text { restrictions; } \\
\text { - technical barriers } \\
\text { to trade; } \\
\text { - sanitary and } \\
\text { phytosanitary } \\
\text { measures; } \\
\text { - rules of origin; } \\
\text { - local component } \\
\text { requirements. }\end{array}$ & \begin{tabular}{|l|} 
2. Effectiveness of \\
customs; \\
3 . The burden of \\
customs \\
procedures \\
(cooperation \\
between the customs \\
of different \\
countries, the \\
complexity of the \\
bureaucratic burden \\
of customs \\
clearance); \\
4 . Transparency of \\
customs \\
authorities.
\end{tabular} & $\begin{array}{l}\text { 5. Availability and } \\
\text { quality of transport } \\
\text { infrastructure; } \\
\text { 6. Availability and } \\
\text { quality of transport } \\
\text { services; } \\
\text { 7. Availability and } \\
\text { application of } \\
\text { information and } \\
\text { communication } \\
\text { technologies } \\
\text { (tracking the } \\
\text { movement of } \\
\text { goods) }\end{array}$ & $\begin{array}{l}\text { 8. Regulatory } \\
\text { environment: } \\
\text { - Investment } \\
\text { policy; } \\
\text { - Requirements for } \\
\text { hiring foreign } \\
\text { workers; } \\
\text { - Currency } \\
\text { regulation in } \\
\text { foreign trade; } \\
\text { 9. Physical } \\
\text { security }\end{array}$ \\
\hline
\end{tabular}

Figure 1. Key trade and investment barriers to GVCs expansion

Source: based on (World Economic Forum, 2015) 
i) physical security reflects the state's ability to maintain a low level of economic crime in order to reduce transaction costs for insurance and security of foreign trade operations by international business.

Obviously, despite the advantages of this classification, in real practice, the boundaries between the spheres of state influence on foreign trade relations in some cases may be rather vague. For example, facilitation of customs control can be seen both as a withdrawal of a non-tariff measure and as an increase in the efficiency of customs services. On the other hand, the introduction of changes in one area may result in changes in other areas. Introduction of rigid quantitative restrictions automatically leads to an increase in the complexity of customs procedures and creates significant risks of lowering the transparency of customs authorities.

The regulation of foreign trade in services also becomes increasingly relevant as there is a significant level of interconnection between the openness of the services market (in particular, transport, logistics, distribution) and the development of infrastructure (World Economic Forum, 2012). In this case, services are considered as a factor that ensures the production and movement of goods along the value chain.

Restricting foreign competition in the sphere of transport services can lead to an increase in the cost of moving products between the links of the chain. Moreover, sticking to the transport services of national companies requires the transshipment of goods at the border from domestic vehicles to vehicles of a foreign carrier, which leads to delays in deliveries and unnecessary costs. This practice becomes totally unacceptable as the competitiveness of international production and sales highly depends on just-in-time deliveries in order to avoid costs for idle standing at the border or storage in the destination country (Sirko, 2014). Thus, barriers to international trade in services have a negative impact on GVCs due to rising import prices and a reduction in export competitiveness.

Each of the above-mentioned components in their interaction and interconnection becomes critical to conducting a productive policy since the omission of certain elements leaves barriers that block or increase the value of international trade. In particular, the experience of transition economies, where the qualitative restructuring of foreign trade turnover did not take place, shows that trade liberalization alone is not able to provide an increase in the efficiency of the country's participation in international division of labour and GVCs without implementation of accompanying domestic reforms in the areas of transport infrastructure, customs services, public administration of foreign economic activity, attraction of innovative FDI, etc.

\section{Compliance of Ukraine's foreign trade policy with the criteria for integration into global value chains}

The policy of the Ukrainian government regarding the functioning of customs authorities, infrastructure, the market for transport services, and a number of other regulatory aspects that have the greatest impact on the scale and quality of integration into GVCs remains unsatisfactory. The existence of a number of tangible obstacles to the cross-border movement of goods in Ukraine can be traced to the duration of export and import operations, as well as to the level of transaction costs (Table 1).

Duration of export-import operations averages 28-29 days, in Poland - 14-17 days, in Turkey 13-14 days, in Sweden - 6-9 days, and in the USA - only 5-6 days. Taking into account that an increase of customs clearance duration by $10 \%$ reduces import volumes by $5-25 \%$ depending on the product group and country of destination (Ostashko, 2011), it can be argued that

Table 1

Average duration and value of foreign trade operations in some countries

\begin{tabular}{|l|c|c|c|c|c|}
\hline \multirow{2}{*}{ Countries } & \multicolumn{2}{|c|}{ Export } & \multicolumn{2}{c|}{ Import } & $\begin{array}{c}\text { Corruption } \\
\text { Perceptions Index }\end{array}$ \\
\cline { 2 - 6 } & Duration, days & Value, USD & Duration, days & Value, USD & 20 \\
\hline Venezuela & 56 & 3490 & 82 & 3695 & 25 \\
\hline Ukraine & 29 & 1880 & 28 & 2455 & 28 \\
\hline Russia & 22 & 2401 & 21 & 2595 & 42 \\
\hline Romazil & 13 & 2215 & 17 & 2275 & 43 \\
\hline Turkey & 13 & 1485 & 13 & 1495 & 50 \\
\hline Poland & 13 & 990 & 14 & 1235 & 60 \\
\hline USA & 17 & 1050 & 14 & 1315 & 73 \\
\hline Great Britain & 6 & 1005 & 4 & 1050 & 76 \\
\hline Germany & 9 & 905 & 7 & 940 & 78 \\
\hline Sweden & 9 & 725 & 6 & 735 & 89 \\
\hline Finland & 9 & 615 & 7 & & 89 \\
\hline
\end{tabular}

Source: based on (World Bank, 2014; Transparency International, 2015) 
there is a significant limiting effect on the participation of Ukrainian producers in GVCs from expenditures related to imperfect tax systems, bureaucratic burden, volatile legislation, poor customs services, etc.

A similar situation is observed in the average cost of transporting the container through the customs border: in countries with a low level of economic development, it in most cases exceeds two thousand USD, while for most OECD countries it is less than one thousand USD. Shcherbata (2011) estimates that the share of customs procedures costs in Ukraine is about 4-5\% of total trade costs, which approximately equals the current average import tariff. At the same time, transaction costs make up $40 \%$ of Ukrainian business profits from foreign trade, while in developed countries this indicator is 3-5\% (Osadcha, 2009).

There is a certain correlation between the scale of the barrier in foreign trade and the level of the index of perceptions of corruption in the country. Table 1 shows that The US and European countries with corruption perceptions within the 60-89 range have already managed to create far more favourable conditions for international trade than Ukraine with an indicator of 25. The high level of corruption in Ukraine is one of the key factors reducing the effectiveness of customs authorities and creating significant barriers to foreign economic activity. For instance, after the customs clearance of goods in 2013, only 50\% of the fees were paid to the state budget, the rest was lost because of corruption; the total annual amount of the loss is estimated at up to 40 billion UAH (Paskhaver, 2014).

According to the Global Competitiveness Report 2015-2016 (Schwab, 2015), despite one of the lowest levels of import tariff in the world, Ukraine takes 113th place out of 140 countries in the competitiveness rating by indicator "burden of customs procedures." It should be noted that the use of opaque and complicated customs clearance procedures in Ukraine to a large extent resulted in the imposition of more stringent requirements for its tariffliberalization from the WTO side. Hammels (2015) estimates that the costs incurred by businesses in delaying the movement of goods at the customs border for one day are equivalent to an additional duty of $0.6-2.1 \%$; the most sensitive to time delays is trade in intermediate products.

In the field of infrastructure, the situation in Ukraine, according to this rating, is not much better. Among the 140 surveyed countries, Ukraine occupies a relatively high place only in terms of railways quality (28th), but much lower - in seaport infrastructure (108th) and air transport (97th), automobile roads are in a disastrous condition (132nd). The quality of the logistics is at a somewhat higher level. According to Arvis (2014), Ukraine ranks 72nd among 160 countries by "Logistic Performance Index" and $52 \mathrm{nd}$ in terms of tracking the movement of goods.

Ukraine also has a number of unresolved issues in export control related to the identification of goods, technologies, and services. Regulatory, organizational, technical, and informational solution to this problem will significantly improve the efficiency of Ukraine's integration into GVCs that cover trade in goods, services, and technologies of dual use. The ratio of goods, technologies, and services that are actually subject to export control standards to goods, technologies, and services that have only external features of such products is 1 to 9 in Ukraine. It is obvious that such a proportion requires the organized identification of goods, technologies, and services, which, on the one hand, keeps 90 per cent of export in goods, technologies, and services (that have only external signs of export control objects) unobstructed and, from another, applies export control norms and procedures to the rest of exports where it's really necessary.

Control of dual-use technologies remains the riskiest moment in Ukraine's export control system. Dualuse technology is rather specific: on the one hand, it is based on scientific and technical achievement or intellectual property; on the other hand, the technology must contain certain consumer properties, that is, the scientific and technological achievement must be brought to the level of the product in order to become a technology. As a rule, the second component is financially more valuable, although the first determines the intellectual potential of technology. Transmission of the intellectual part of technology allows determining its essence, but to bring it to the product is the necessary stage of introduction into production. This specificity of technology when it is promoted to the market requires effective management, including strengthening of export control (Vladimirov, 2011).

The need for state support and management of technology transfer, primarily dual-use technologies, is especially important in modern Ukraine. The scientific and technological base created in previous years is used extremely inefficiently under conditions of the transformation period. Many research organizations working on state defence orders, having the highest scientific and technical potential and creating the intellectual property of the world level, are not able to bring them to the level of high-tech technology, which is why they are forced to bring to the market a "semifinished products." Hence, the value of the goods is lower than the objective value of such objects. The inadequate assessment of the latest technology and know-how in exports does not bring the country a proper economic benefit, especially as it concerns the know-how, the transfer of which is mostly carried out at prices much lower than world ones, and often for free.

A clear system of interaction between the export control authorities, central and other executive authorities during the exchange of information and joint activities aimed at ensuring the proper control of international transfers of goods and their use in accordance with the international obligations and guidelines adopted by Ukraine in export control and non-proliferation become significantly important. 


\section{Conclusions}

Thanks to technological development and the cheapening of international trade, GVCs have become the main and most important component of the global economy, which determines the pace of world development. The growing fragmentation of production at the international level, development of the international specialization of countries in specific production processes and business functions, and the growing role of international intermediaries in global trade led to significant practical value and an increasing interest in the concept of GVCs.

On the other hand, the effective entry of national economy to GVCs requires a number of fundamental changes in approaches to the regulation of foreign trade. When import components become an important source of increasing competitiveness for exports, changes in the approaches and criteria of the customs and tariff policy are necessary. Stimulating the import of materials and components becomes desirable in those cases where it is connected with the perspective increase of finished products export. In addition, GVCs significantly complicates the set of foreign trade policy measures required for their servicing. Mechanisms such as simplifying trade procedures and multiple unimpeded border crossings, promoting advanced quality and safety management systems, protecting intellectual property rights in partner countries become crucial.

In Ukraine, poor attention is paid to the use of the internal potential of the foreign trade activity intensification through the participation in GVCs. The regulatory policy aimed at ensuring the proper functioning of the customs authorities and the transport and communication infrastructure of foreign economic activity, which creates significant obstacles to the crossborder movement of goods and Ukraine's integration into international production and distribution networks, remains unsatisfactory. Instead, reducing the level of bureaucratic obstacles at the customs will give Ukraine much more advantages than for leading economies in the world.

\section{References:}

Arvis, J.-F. (2014). Connecting to Compete 2014: Trade Logistics in the Global Economy. Washington: World Bank. Barrientos, S. (2010). Economic and Social Upgrading in Global Production Networks: Developing a Framework for Analysis. Retrieved from: http://www.capturingthegains.org/pdf/ctg-wp-2010-03.pdf

Cattaneo, O. (2010). Global Value Chains in a Postcrisis World: A Development Perspective. Washington: The World Bank.

Frederick, S. (2010). The Global Apparel Value Chain, Trade and the Crisis: Challenges and Opportunities for Developing Countries. Washington: The World Bank.

Gereffi, G. (2010). The Offshore Services Industry: A Global Value Chain Approach. Durham: Center on Globalization, Governance \& Competitiveness.

Hummels, D. (2012). Time as a Trade Barrier. Washington: NBER Working Paper.

Nicita, A. (2013). Global Supply Chains: Trade and Economic Policies for Developing Countries. Geneva: UNCTAD. Osadcha, N. V. (2009). Systemic representation of the regulatory customs regime under conditions of foreign economic activity globalization. Bulletin of Economic Science of Ukraine, 1, 134-146. (in Ukrainian)

Ostashko, T. O. (2011). Special WTO measures to protect agricultural food markets. Kyiv: Institute of economy and forecasting. (in Ukrainian)

Koval, V., Slobodianiuk, O., Yankovyi, V. (2018). Production forecasting and evaluation of investments using Allen two-factor production function. Baltic Journal of Economic Studies, 4(1), 219-226. doi: 10.30525/2256-0742) 2018-4-1-219-226

Park, A. (2013). Supply Chain Perspectives and Issues: A Literature Review. Geneva: WTO Publications.

Paskhaver, O. (2014). Repair the country. Information-analytical weekly "Dzerkalo Tyzhnya. Ukraine", 7, 1-5.

Sirko, A. V. (2014). Economic theory. Political economy. Kyiv: Center for educational literature. (in Ukrainian)

Shcherbata, N. Z. (2011). Foreign Economic Policy of the European Union in free trade areas. Lutsk: Volyn National Institute. (in Ukrainian)

Shwab, K. (2015). The Global Competitiveness Report 2015-2016. Geneva: WEF.

Transparency International (2015). Corruption Perception Index. Retrieved from: http://www.transparency.org/ country\#UKR

Vladimirov, T. O. (2011). Conceptual framework for the development of the export control system of Ukraine. Scientific Herald of the Academy of Municipal Management, 4, 207-213.

UNCTAD (2014). Trade and Development Report, 2014: Global Governance and Policy Space for Development. Geneva: UNCTAD.

World Bank (2014). Doing Business 2015: Going beyond Efficiency. Washington: World Bank Group.

World Economic Forum (2012). The Shifting Geography of Global Value Chains: Implications for Developing Countries and Trade Policy Geneva: WEF, 2012.

World Economic Forum (2015). Enabling Trade: Increasing the Potential of Trade Reforms. Geneva: WEF. 